\title{
METHANE PRODUCTION POTENTIAL FROM VARIETY OF UNPRINTED PAPERS
}

\author{
Vilis Dubrovskis, Imants Plume, Indulis Straume \\ Latvia University of Life Sciences and Technologies, Latvia \\ vilisd@inbox.lv,imants.plume@inbox.lv, indulis.straume@1lu.lv
}

\begin{abstract}
Politicians in Latvia have decided to decrease support for biogas production. The new renewable biomass resources should be investigated to provide inexpensive and cost-effective methane production. Every year a lot of paper waste goes to landfills. Paper waste has a low density and the cost of transporting wastes to the landfill is high. In the past paper waste was used to produce new paper, but now there is no any paper mill in Latvia. There are some publications on the use of paper for biogas production. The purpose of the study is assessment of the methane volume obtainable from various unprinted papers in the anaerobic fermentation process. Investigation was provided in 16 bioreactors operated in batch mode at $38{ }^{\circ} \mathrm{C}$. Paper waste was filled into 14 bioreactors and inoculum only was filled into two bioreactors for control. The yields of methane $0.506 \mathrm{l} \cdot \mathrm{g}_{\text {DOM }}^{-1}$ after 41 days of anaerobic digestion of office paper, $0.386 \mathrm{l} \cdot \mathrm{g}^{-1}$ DOM of toilet paper, $0.375 \mathrm{l} \cdot \mathrm{g}^{-1}$ DOM of packaging paper and $0.388 \mathrm{l} \cdot \mathrm{g}^{-1}$ DOM of cardboard were obtained. The study demonstrates that paper waste is a good raw material for the production of methane.
\end{abstract}

Key words: methane, office paper, toilet paper, packaging paper, cardboard.

\section{Introduction}

Support for biogas production is reduced by some legislative acts in Latvia, e.g. the owners of the areas cultivating maize for biogas plants are excluded from the range of duty-free tax receivers on diesel for maize biomass growing. New renewable biomass resources should be investigated to replace usage of maize biomass and to provide inexpensive and cost effective biomethane production.

Paper wastes are major organic components in municipal solid waste suitable for biogas production. $163 \mathrm{~kg}$ of paper wastes per inhabitant were produced in Latvia every year. Every year a lot of paper waste goes to landfills. Paper waste has a low density and the cost of passing it to the landfill in Latvia is high. In the past paper waste was used to produce new paper, but now there is no running paper mill in Latvia.

Nigerian scientists did an $\mathrm{AD}$ experiment for 30 days at temperature $27-35^{\circ} \mathrm{C}$, using three 251 plastic vessels filled in with 17 Lof substrate composed of: poultry droppings with inoculate (fresh cattle rumen content) in the bio-digester A; co-digestion ofpoultry droppings, inoculate with untreated corn cob and waste papers in the bio-digester B; co-digestion of poultry droppings, inoculate with pretreated corn cob and waste paper in the bio-digester C; pre-treatment of corn cob and waste papers include mechanical grinding and thermal boiling at $100{ }^{\circ} \mathrm{C}$ for an hour. "The results showed that poultry droppings alone in the bio-digester A gave a cumulative average biogas volume of $3452 \mathrm{~cm}^{3}$ $\left(115 \mathrm{~cm}^{3} \cdot \mathrm{day}^{-1}\right)$ and poultry droppings plus untreated co-substrates in the bio-digester $\mathrm{B}$ gave a cumulative average biogas volume of $4811 \mathrm{~cm}^{3}\left(160.3 \mathrm{~cm}^{3} \cdot\right.$ day $\left.^{-1}\right)$, while poultry droppings plus treated co-substrates in the bio-digester $\mathrm{C}$ gave a cumulative average biogas volume of $6454 \mathrm{~cm}^{3}$ $\left(215.1 \mathrm{~cm}^{3} \cdot\right.$ day $\left.^{-1}\right) "[1]$.

Another research was provided on lignocellulosic materials, paper and paper board (PPB) that are processed for their fabrication. "This study evaluated correlations of methane yields and Monod and Gompertz kinetic parameters with structural carbohydrates, lignin, and ash concentration of five types of PPBs. All components were used as single and combined independent variables in linear regressions to predict the methane yield, maximum specific methanogenic activity (SMAmax), saturation constant $(K s)$, and the lag phase $(\lambda)$. The results showed the methane yields ranging from $69.2 \pm 8.61$ to $97.2 \pm 2.29 \%$ of PPB substrates provided. The overall findings of this study are: (i) combinations of structural carbohydrates, lignin and ash used as ratios of degradable to either non degradable or slowly degradable fractions predict AD kinetic parameters of PPB materials better than singleindependent variables; and (ii) other components added during their fabrication may also influence both the methane yield and kinetic parameters" [2].

Another Nigerian scientists' study aimed to find the biogas production potential of paper waste alone (PW-A) and paper waste blend : cow dung (PW:CD) in the ratio 1:1 was provided into two 50L biodigesters in the ratio of 3:1 of water to waste under 45 day retention period at the temperature 26$43^{\circ} \mathrm{C}$. "The physicochemical parameters of the wastes were determined including microbial analysis. 
The results obtained showed that PW had a cumulative gas yield of $6.23 \pm 0.07 \mathrm{dm}^{3} \cdot \mathrm{kg}^{-1}$ of slurry with the flash point on the 2 nd day even though gas production reduced drastically, while the flammability discontinued and resumed after 14 days. Blending increased the cumulative gas yield to $9.34 \pm 0.11 \mathrm{dm}^{3} \cdot \mathrm{kg}^{-1}$, slurry representing more than $50 \%$ increase. The onset of gas flammability took place on the 6th day and was sustained throughout the retention period" [3].

Swedish researchers studied anaerobic fermentation of paper tube residuals as substrate for biogas (methane) production with addition of both $2 \% \mathrm{NaOH}$ and $2 \% \mathrm{H}_{2} \mathrm{O}_{2}$. "Digestion of the pre-treated materials at these conditions yielded $493 \mathrm{~N} \mathrm{ml} \cdot \mathrm{g}^{-1}$ vs methane, which was $107 \%$ more than the untreated materials. In addition, the initial digestion rate was improved by $132 \%$ compared to the untreated samples. The addition of $\mathrm{NaOH}$ was, besides the explosion effect, the most important factor to improve the biogas production" [4].

The effect of waste paper of different amount $(0,4,8,12$ or $20 \mathrm{~g})$ on biogas production from its co-digestion with fixed amount of cow dung $5 \mathrm{~g}$ and water hyacinth $5 \mathrm{~g}$ was studied at room temperature in five batch reactors for over 60 days period at the University of Port-Harcourt. "Waste paper addition was varied for a fixed amount of cow dung and water hyacinth until maximum biogas production was achieved. Biogas production was measured indirectly by the water displacement method. The production of biogas showed a parabolic relationship as the amount of waste paper $(\mathrm{g})$ increased with a goodness of fit of 0.982. Maximum biogas volume of 1.11 litres was observed at a waste paper amount of $17.5 \mathrm{~g}$, which corresponds to $10.0 \%$ total solids of the biomass in $250 \mathrm{~mL}$ solution" [5].

Municipal solid waste contains $20-40 \%$ paper influencing its anaerobic digestion usually. Scientists from the Brazil University of the Sinos Valley provided experimental research on anaerobic co-digestion of the organic fraction of municipal solid waste (OFMSW) with fruit and vegetable waste $(\mathrm{FVM})$ in mixing ratios $1: 0,1: 1,3: 1$ and $0: 1$ in bath $\mathrm{AD}$ process at temperature $35^{\circ} \mathrm{C}$. "The $1: 3$ mixing ratio of OFMSW:FVW (VS basis) showed the optimal performance, reaching the highest average cumulative biogas yield (433.9 N ml. $\left.\mathrm{g}^{-1} \mathrm{VS}\right)$, highest average methane yield (396.6 Nml. $\left.\mathrm{g}^{-1} \mathrm{vs}\right)$ and the highest average VS removal rate (54.6\%)" [6].

The initial percentage of paper wastes in OFMSW, however, was not provided in this scientific article. Also, the investigations mentioned above do not include the data on biogas and methane production in the $\mathrm{AD}$ process of different types of paper wastes in the temperature range $36-40{ }^{\circ} \mathrm{C}$ used in most biogas cogeneration plants in Latvia.

The aim of this study is evaluation of the biogas and methane production potential from different types of paper biomass, as there are no previous investigations on the biogas and methane yield from paper biomass in Latvia.

\section{Materials and methods}

Before fermentation the raw materials (office paper, toilet paper, packaging paper and cardboard paper) samples were analysed for dry matter and organic matter content before the experiment. Data on the content of the organic matter were used for optimizing of the organic load of substrate.

The widely applied methods [6-8] were used for the AD process investigation. For this research in 16 experimental bioreactors with volume of 0.75 litres similar methods are used, as described in [6]. Two bioreactors for control were filled with $500.0 \pm 0.2 \mathrm{~g}$ inoculums and the rest bioreactors were filled with mixtures of inoculums $(500 \mathrm{~g})$ and added paper biomass $(10 \pm 0.005 \mathrm{~g})$, according to the experimental plan, Table 1 .

"Dry organic matter (DOM) content was determined by weighting the initial biomass samples dried in the thermostat at $105{ }^{\circ} \mathrm{C}$ and processed in the oven (type Nabertherm) to provide the aching process within a special heating cycle with the maximal cycle temperature $550{ }^{\circ} \mathrm{C}$.

All the components were carefully mixed together and filled in the bioreactors. All bioreactors were placed in a single heated camera at the same time before anaerobic digestion. Gases released from each bioreactor were collected in storage bags positioned outside of the heated camera.Gas volumes collected in storage bags were measured regularly using the flow meter (Ritter drum-type gas meter). The composition of gases, including oxygen, carbon dioxide, methane and hydrogen sulphide, was measured by help of the gas analyser (model GA 2000). The substrate $\mathrm{pH}$ value was measured 
before and after finishing off the $\mathrm{AD}$ process, using a $\mathrm{pH}$ meter (model PP-50) with accessories. Scales (type KFB 16KO2) was used for weighting (accuracy $\pm 0.2 \mathrm{~g}$ ) of the total weight of substrates before and after the $\mathrm{AD}$ process.

Fermented cattle manure was utilized as inoculums, and it has very low organic matter content providing low biogas volumes released from pure inoculums (filled in control bioreactors R1 and R16), resulting in small biogas and methane volumes to be subtracted in calculations of true biogas and methane volumes from the added biomass. The $\mathrm{AD}$ process was provided until biogas release was finished. The experimental data were processed using appropriate statistical methods [7].

\section{Results and discussion}

The results of the investigation of sample substrates, including inoculums, before starting of the $\mathrm{AD}$ process are shown in Table 1.

Results of analyses of raw material samples before anaerobic digestion

\begin{tabular}{|c|c|c|c|c|c|c|c|c|}
\hline $\begin{array}{c}\text { Bio- } \\
\text { reactors }\end{array}$ & Raw material & $\mathbf{p H}$ & $\begin{array}{c}\text { TS, } \\
\mathbf{\%}\end{array}$ & $\begin{array}{c}\text { TS, } \\
\mathbf{g}\end{array}$ & $\begin{array}{c}\mathbf{A S H}, \\
\mathbf{\%}\end{array}$ & $\begin{array}{c}\text { DOM, } \\
\mathbf{\%}\end{array}$ & $\begin{array}{c}\text { DOM, } \\
\mathbf{g}\end{array}$ & $\begin{array}{c}\text { Weight, } \\
\mathbf{g}\end{array}$ \\
\hline R1; R16 & IN & 7.59 & 3.75 & 18.75 & 31.34 & 68.66 & 12.874 & 500 \\
\hline R2-R5 & OP & - & 92.64 & 9.264 & 11.95 & 88.05 & 8.156 & 10 \\
\hline R6-R8 & TP & - & 90.85 & 9.085 & 1.35 & 98.65 & 8.962 & 10 \\
\hline R9- R11 & PP & - & 92.2 & 9.220 & 14.34 & 85.66 & 7.898 & 10 \\
\hline R12-R15 & C & - & 91.5 & 9.150 & 13.86 & 86.14 & 7.882 & 10 \\
\hline R2-R5 & 10 OP + 500IN & 7.60 & 5.49 & 28.014 & 24.93 & 75.07 & 21.03 & 510 \\
\hline R6- R8 & $10 \mathrm{TP}+500 \mathrm{IN}$ & 7.59 & 5.46 & 27.835 & 21.93 & 78.07 & 21.836 & 510 \\
\hline R9-R11 & $10 \mathrm{PP}+500 \mathrm{IN}$ & 7.59 & 5.48 & 27.97 & 25.73 & 74.27 & 20.772 & 510 \\
\hline R12-R15 & $10 \mathrm{C}+500 \mathrm{IN}$ & 7.60 & 5.47 & 27.900 & 25.61 & 74.39 & 20.756 & 510 \\
\hline
\end{tabular}

Note: IN - inoculum; $O P$ - office paper; $T P$ - toilet paper; $P P$ - packaging paper; $C$ - cardboard; ASH - ashes; TS - total solids; DOM - dry organic matter (on raw substrate basis); RI-R16 bioreactors.

As shown in Table 1, all paper types have a high dry matter and organic dry matter content. The biggest organic dry matter content is in toilet paper, because it has very few impurities.

Almost completely fermented cattle manure was used as inoculum and it was fermented in the control bioreactors R1 and R16. Very low average methane yield $0.063 \mathrm{~L}$ was obtained from the control bioreactors, and it was less than 2.2 percent of the average yields from the other bioreactors with paper waste addition. Biogas and methane yields from the bioreactors R2-R15 with added paper biomass are shown in Table 2 and Fig. 1 with already subtracted average values of biogas and methane obtained from the control bioreactors R1 and R16 filled in with pure inoculum. As shown in Table 2, the best average methane content in the biogas and methane yield was obtained from the bioreactors filled in with office paper.Also, the average yield of biogas was significantly higher than that of other types of paper. This could be explained by the composition of office paper.

A good methane yield was extracted also from toilet paper. This can be explained by the fact that toilet paper contains a lot of organic matter and has small content of impurities.

Table 2

Production of biogas and methane

\begin{tabular}{|c|c|c|c|c|c|c|}
\hline Bioreactor & Raw material & Biogas, l & $\begin{array}{c}\text { Biogas, } \\
{\mathbf{l} \cdot \mathbf{g}^{-1} \text { DoM }}^{-1}\end{array}$ & $\begin{array}{c}\text { Methane, } \\
\text { aver. \% }\end{array}$ & Methane, I & $\begin{array}{c}\text { Methane, } \\
\mathbf{l \cdot g}^{-1} \text { DoM }\end{array}$ \\
\hline R1 500g IN & $500 I N$ & 0.5 & 0.039 & 17.80 & 0.089 & 0.007 \\
\hline R16 500g IN & $500 I N$ & 0.2 & 0.016 & 18.50 & 0.037 & 0.003 \\
\hline Average: R1, R16 & $\mathbf{5 0 0 I N}$ & $\mathbf{0 . 3 5}$ & $\mathbf{0 . 0 2 8}$ & $\mathbf{1 8 . 1 5}$ & $\mathbf{0 . 0 6 3}$ & $\mathbf{0 . 0 0 5}$ \\
\hline
\end{tabular}


Table 2 (continued)

\begin{tabular}{|c|c|c|c|c|c|c|}
\hline Bioreactor & Raw material & Biogas, 1 & $\begin{array}{l}\text { Biogas, } \\
l \cdot g^{-1} \text { DOM }\end{array}$ & $\begin{array}{l}\text { Methane, } \\
\text { aver. \% }\end{array}$ & Methane, 1 & $\begin{array}{c}\text { Methane, } \\
l \cdot \mathrm{g}^{-1} \text { DOM }\end{array}$ \\
\hline R2 & $500 \mathrm{IN}+10 \mathrm{OP}$ & 6.55 & 0.803 & 55.79 & 3.653 & 0.448 \\
\hline R3 & $500 \mathrm{IN}+10 \mathrm{OP}$ & 7.45 & 0.913 & 53.08 & 3.955 & 0.485 \\
\hline $\mathrm{R} 4$ & $500 \mathrm{IN}+10 \mathrm{OP}$ & 8.05 & 0.987 & 55.35 & 4.456 & 0.546 \\
\hline R5 & $500 \mathrm{IN}+10 \mathrm{OP}$ & 8.65 & 1.061 & 51.99 & 4.497 & 0.551 \\
\hline $\begin{array}{c}\text { Average: R2-R5 } \\
\pm \text { st.dev. }\end{array}$ & $500 I N+100 P$ & $\begin{aligned} 7.68 \\
\pm 0.90 \\
\end{aligned}$ & $\begin{array}{c}0.941 \\
\pm 0.110 \\
\end{array}$ & $\begin{array}{l}54.05 \\
\pm 1.82 \\
\end{array}$ & $\begin{aligned} 4.140 \\
\pm 0.408 \\
\end{aligned}$ & $\begin{array}{c}0.506 \\
\pm 0.050 \\
\end{array}$ \\
\hline R6 & $500 \mathrm{IN}+10 \mathrm{TP}$ & 6.85 & 0.764 & 52.79 & 3.616 & 0.403 \\
\hline R7 & $500 \mathrm{IN}+10 \mathrm{TP}$ & 6.25 & 0.697 & 52.18 & 3.261 & 0.364 \\
\hline $\mathrm{R} 8$ & $500 \mathrm{IN}+10 \mathrm{TP}$ & 6.45 & 0.719 & 54.33 & 3.504 & 0.391 \\
\hline $\begin{array}{c}\text { Average: R6-R8 } \\
\pm \text { st.dev. }\end{array}$ & $500 I N+10 T P$ & $\begin{array}{r}0.52 \\
\pm 0.31 \\
\end{array}$ & $\begin{array}{c}0.727 \\
\pm 0.034 \\
\end{array}$ & $\begin{array}{r}53.10 \\
\pm 1.11 \\
\end{array}$ & $\begin{array}{r}3.460 \\
\pm 0.181 \\
\end{array}$ & $\begin{array}{r}\mathbf{0 . 3 8 6} \\
\pm 0.020 \\
\end{array}$ \\
\hline R9 & $500 \mathrm{IN}+10 \mathrm{PP}$ & 5.65 & 0.715 & 49.68 & 2.807 & 0.355 \\
\hline R10 & $500 \mathrm{IN}+10 \mathrm{TP}$ & 5.75 & 0.728 & 54.61 & 3.140 & 0.397 \\
\hline $\mathrm{R} 11$ & $500 \mathrm{IN}+10 \mathrm{TP}$ & 5.55 & 0.702 & 53.14 & 2.949 & 0.373 \\
\hline $\begin{array}{c}\text { Average: R9-R11 } \\
\pm \text { st.dev. }\end{array}$ & $500 I N+10 T P$ & $\begin{array}{r}5.65 \\
\pm 0.10 \\
\end{array}$ & $\begin{array}{r}0.715 \\
\pm 0.013 \\
\end{array}$ & $\begin{array}{r}52.48 \\
\pm 2.53 \\
\end{array}$ & $\begin{array}{r}2.965 \\
\pm 0.167 \\
\end{array}$ & $\begin{array}{r}\mathbf{0 . 3 7 5} \\
\pm 0.021 \\
\end{array}$ \\
\hline $\mathrm{R} 12 \mathrm{C}$ & $500 \mathrm{IN}+10 \mathrm{C}$ & 4.95 & 0.628 & 54.18 & 2.862 & 0.340 \\
\hline $\mathrm{R} 13$ & $500 \mathrm{IN}+10 \mathrm{C}$ & 6.15 & 0.780 & 52.82 & 3.253 & 0.412 \\
\hline R14 & $500 \mathrm{IN}+10 \mathrm{C}$ & 6.35 & 0.806 & 51.69 & 3.282 & 0.416 \\
\hline $\mathrm{R} 15$ & $500 \mathrm{IN}+10 \mathrm{C}$ & 5.75 & 0.729 & 53.04 & 3.050 & 0.387 \\
\hline $\begin{array}{c}\text { Average: R12-R15 } \\
\pm \text { st.dev. }\end{array}$ & $500 I N+10 C$ & $\begin{array}{r}5.80 \\
\pm 0.62 \\
\end{array}$ & $\begin{array}{r}0.735 \\
\pm 0.079 \\
\end{array}$ & $\begin{array}{r}52.93 \\
\pm 1.02 \\
\end{array}$ & $\begin{array}{r}3.067 \\
\pm \mathbf{0 . 1 9 6} \\
\end{array}$ & $\begin{array}{r}\mathbf{0 . 3 8 8} \\
\pm \mathbf{0 . 0 3 5} \\
\end{array}$ \\
\hline
\end{tabular}

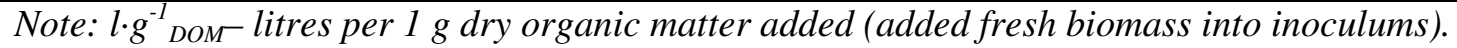

Very good methane yields were obtained from all types of paper. The lowest yield on average was obtained from packaging paper. The amount of biogas extracted from office paper is slightly higher than reported by other [5] researchers.

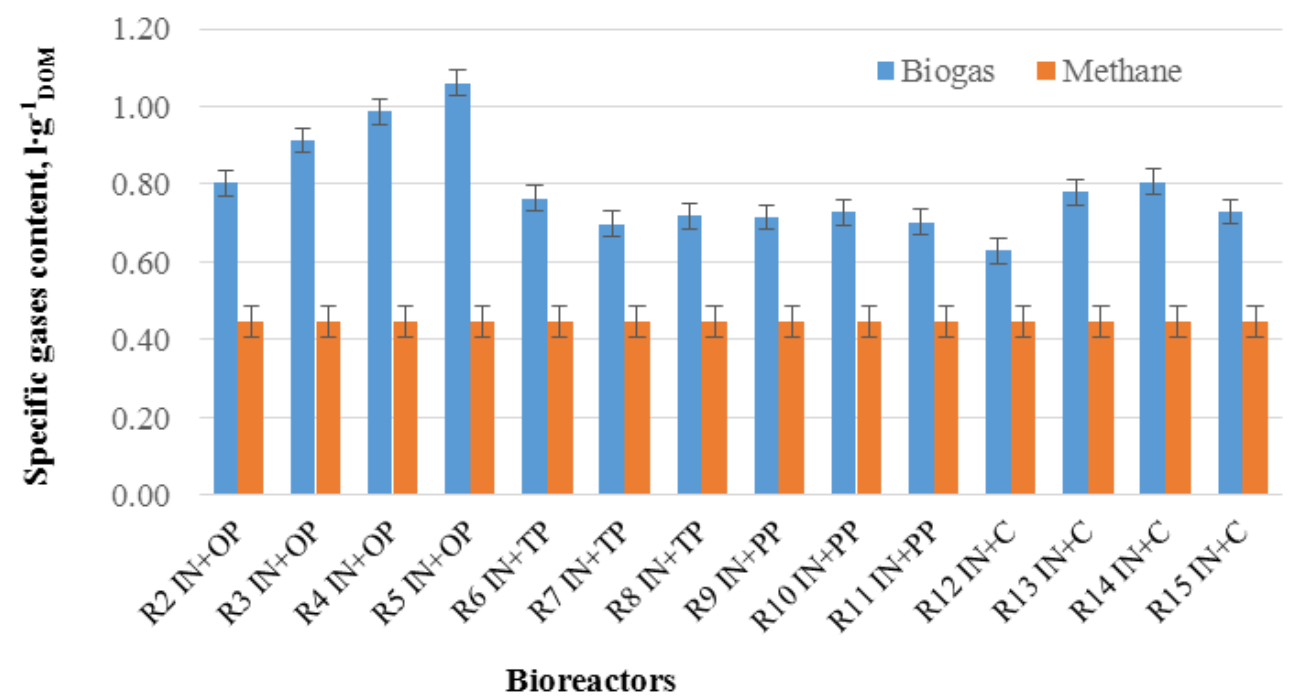

Fig. 1. Specific biogas and methane output from each bioreactor: $\mathrm{IN}$ - inoculum; OP - office paper; TP - toilet paper; $\mathrm{PP}$ - packaging paper; $\mathrm{C}$ - cardboard

The average methane contents from bioreactors loaded with different papers are shown in Figure 3. The highest average methane yield $0.506 \mathrm{l} \cdot \mathrm{g}^{-1}$ DomWas obtained from the bioreactors R2-R5, where office paper was filled in. The obtained result is much higher compared to that, reported by the Indonesian researchers, methane yield $0.058 \mathrm{l} \cdot \mathrm{g}^{-1}$ Dom from cattle dung : newspapers at ratio $1: 1$ and methane yield $0.106 \mathrm{l} \cdot \mathrm{g}^{-1}$ DOM from the same substrate with BS4 enzyme addition during a 5-week 
period [10]. The results are not directly comparable, as fresh cow dung was used by the Indonesian researchers as inoculums, while cattle manure at finished fermentation stage was used in our experimental research.

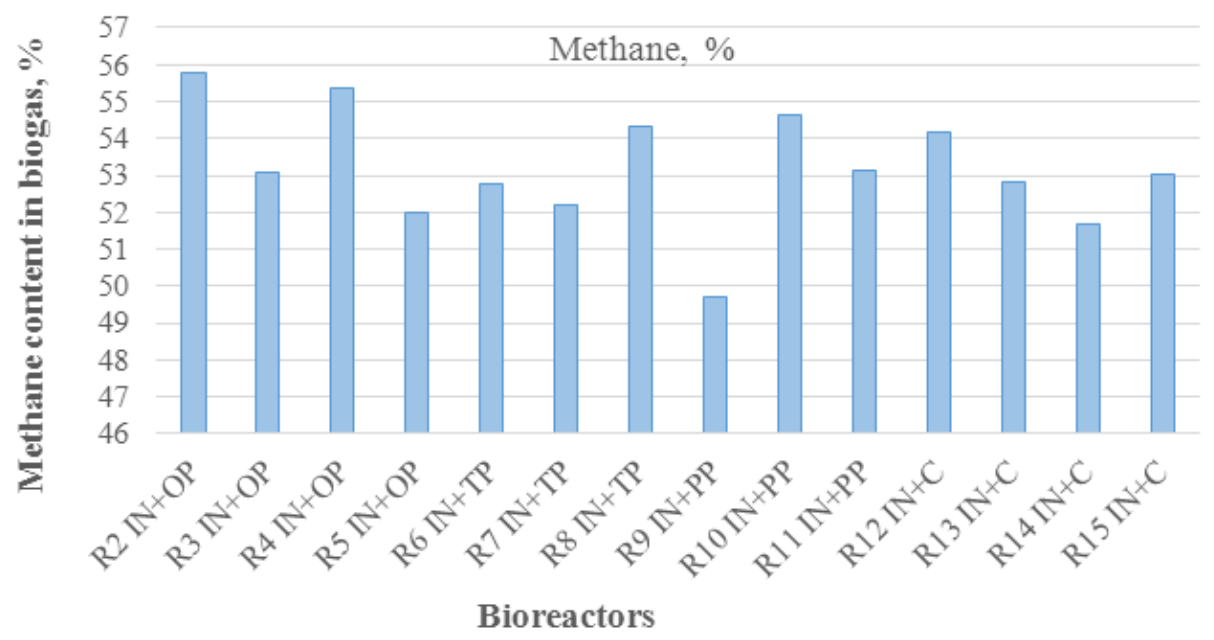

Fig. 2. Average specific methane output and methane content in bioreactors with different paper wastes: IN - inoculum; OP - office paper; $\mathrm{TP}$ - toilet paper; $\mathrm{PP}$ - packaging paper; $\mathrm{C}$ - cardboard

The higher methane content was obtained in biogas from office paper that was by $0.8-3.0 \%$ higher compared to the other types of paper waste investigated. This evidence may be explained due to the similar type of carbohydrates contained in all paper waste.

\section{Conclusions}

1. All types of papers processed in anaerobic fermentation gave very good methane yields.

2. The methane volume obtained from office paper was by $31.1 \%$ higher than released from toilet paper.

3. The methane yield obtained from office paper was by $34.9 \%$ higher than obtained from packaging paper.

4. The methane yield obtained from cardboard was by $30.4 \%$ lower compared to that from office paper.

5. Paper residues and paper waste are good raw materials for biogas producing and can be recommended for using in biogas plants.

\section{References}

[1] Aremu M.O., Agarry S. E. Enhanced biogas production from poultry droppings using corn-cob and waste paper as co-substrate. International Journal of Engineering Science and Technology, 02, 2013, pp. 247-254.

[2] Gonzalez-Estrella C.J., Asato M., Amber J.C., Stone J.J., Gilcrease P.C. Effect of structural carbohydrates and lignin content on the anaerobic digestion of paper and paper board materials by anaerobic granular sludge,Biotechnol. Bioeng.,114, 2017, pp. 951-960.

[3] Ofoefule A.U., Nwankwo J.I., Ibeto C.N. Biogas Production from Paper Waste and its blend with Cow dung. Advances in Applied Science Research, 2010, 1(2), pp. 1-8.

[4] Teghammar A., Yngvesson J., Lundin M., Taherzadeh M.T., Horváth I.S. Pretreatment of paper tube residuals for improved biogas production. Bioresource Technology, 101(4), 2010, pp. 12061212.

[5] Momoh O.L.Y., Nwaogazie I.L. Effect of Waste Paper on Biogas Production from Co-digestion of Cow Dung and Water Hyacinth in Batch Reactors. Journal of Applied Sciences and Environmental Management, 12(4), 2008, pp. 95-98.

[6] Pavi S., Kramer L.E., Gomes L.P., Miranda L.A.S. Biogas production from co-digestion of organic fraction of municipal solid waste and fruit and vegetable waste. Bioresource Technology, 228, 2017, pp. 362-367. 
[7] Dubrovskis V., Plume I., Straume I. Anaerobic co-fermentation of molasses and oil with straw pellets. Agronomy Research, 16(3), 2018, pp. 688-695.

[8] Thran D. Methodenhandbuch Energetische Biomassenutzung, (Methods Manual Energetic use of biomass). Leipzig, 2010, 93 p. (In German).

[9] VDI 4630. Vergärung organischer Stoffe Substrat charakterisierung, Probenahme, Stoffdatenerhebung, Gärversuche. Vereindeutscher Ingenieure (Fermentation of organic substances Substrate characterization, sampling, substance data collection, fermentation tests. German engineers), Düsseldorf, 2006, pp. 48. (In German).

[10] Haryati T., Sinurat A.P., Listian B., Hamid H., Purwadaria T. Application of BS4-Enzyme on the Methane Production from Mixture of Cattle Manures and Waste Paper, JITV, 2016, 21( 4), pp. 238-243. 